\title{
Environmental variables and errors in the preparation and administration of medicines
}

\author{
Variáveis ambientais e erros no preparo e administração de medicamentos \\ Variables ambientales y errores en la preparación y administración de medicamentos
}

\section{Francisco Gilberto Fernandes Pereira', Márcia Barroso Camilo de Ataíde", Ricardo Leal Silva', Eugenie Desirèe Rabelo Néri', Gerdane Celene Nunes Carvalho', Joselany Áfio Caetano'}

' Universidade Federal do Ceará, Center of Health Sciences. Fortaleza, Ceará, Brazil.

"Universidade de Fortaleza, Undergraduate Course in Medicine. Fortaleza, Ceará, Brazil.

How to cite this article:

Pereira FGF, Caetano JA, Ataíde MBC, Silva RL, Néri EDR, Carvalho GCN. Environmental variables and errors in the preparation and administration of medicines. Rev Bras Enferm [Internet]. 2018;71(3):1046-54.

DOI: http://dx.doi.org/10.1590/0034-7167-2016-0041

Submission: 03-15-2016 Approval: 06-03-2017

\begin{abstract}
Objective: to identify the relationship between environmental factors and errors in the preparation and administration of antibacterial. Method: an observational, cross-sectional study conducted between August and December, 2014 in two clinical units. The sample consisted of 265 doses of medication, observed in different shifts that through a form had the environmental conditions of noise, illumination, humidity, temperature and physical space measured in the preparation and administration stages. Results: the physical dimension for the preparation was inadequate in one unit $\left(3.8 \mathrm{~m}^{2}\right)$, and the items illumination, temperature and noise were extremely oscillating in the three shifts and in the two clinics, with averages generally higher than the recommended for the hospital environment, however, variations in illumination and noise were not statistically significant to cause dose errors or erroneous medicine choice $(p>0.05)$. Conclusion: the environmental variables analyzed may favor medication errors in both the preparation and administration stages.
\end{abstract}

Descriptors: Antibacterial; Patient Safety; Medication Errors; Nursing; Use of Medications.

\section{RESUMO}

Objetivo: identificar a relação entre os fatores ambientais e os erros de preparo e administração de antibacterianos. Método: estudo observacional, transversal, realizado entre agosto a dezembro de 2014 em duas unidades clínicas. A amostra foi composta de 265 doses de medicamentos, observadas em diferentes turnos, que por meio de um formulário tiveram as condições ambientais de ruído, iluminação, umidade, temperatura e espaço físico mensuradas nas etapas de preparo e administração. Resultados: a dimensão física para o preparo foi inadequada em uma unidade $\left(3,8 \mathrm{~m}^{2}\right)$, e os itens iluminação, temperatura e ruído foram extremamente oscilantes nos três turnos e nas duas clínicas, com médias geralmente acima do recomendado para o ambiente hospitalar, porém, as variações de iluminação e ruído não foram estatisticamente significativas para provocar erros de dose ou de escolha errada do medicamento $(p>0,05)$. Conclusão: as variáveis ambientais analisadas podem favorecer erros de medicação tanto na etapa de preparo quanto na administração.

Descritores: Antibacterianos; Segurança do Paciente; Erros de Medicação; Enfermagem; Uso de Medicamentos.

\section{RESUMEN}

Objetivo: identificar la relación entre los factores ambientales y los errores de preparación y administración de antibacterianos. Método: estudio observacional, transversal, realizado entre agosto y diciembre de 2014 en dos unidades clínicas. La muestra fue compuesta de 256 dosis de medicamentos, observadas en diferentes turnos, que por medio de un formulario tuvieron las condiciones ambientales de ruido, iluminación, humedad, temperatura y espacio físico medidos en las etapas de preparación y administración. Resultados: la dimensión física para la preparación fue inadecuada en una unidad $\left(3,8 \mathrm{~m}^{2}\right)$, y los elementos iluminación, temperatura y ruido fueron extremadamente oscilantes en los tres turnos y en las dos clínicas, con medias generalmente por encima de lo 
recomendado para el ambiente hospitalario. Sin embargo, las variaciones de iluminación y ruido no fueron estadísticamente significativas para provocar errores de dosis o de elección errónea del medicamento $(p>0,05)$. Conclusión: las variables ambientales analizadas pueden favorecer errores de medicación tanto en la etapa de preparación como en la de administración.

Descriptores: Antibacterianos; Seguridad del Paciente; Errores de Medicación; Enfermería; Uso de Medicamentos.

\section{CORRESPONDING AUTHORＦrancisco Gilberto Fernandes Pereira～E-mail: gilberto.fp@hotmail.com}

\section{INTRODUCTION}

Providing health care with a focus on minimizing harm to patients is a goal that has gained more prominence in contemporary discussions at all levels of health care. For this purpose to be achieved, it is necessary that human, institutional, technological and environmental factors cooperate to ensure maximum efficiency in all clinical processes involving therapeutic behaviors ${ }^{(1)}$.

In reality, Brazilian hospitals, especially those linked to the Unified Health System (SUS), show that the precariousness of financial resources and the culture of immediate planning favor the provision of services generally in physical structures that do not always meet the prerequisites of legislation, which diverges, therefore, from the patient's safety goals $\mathrm{s}^{(2)}$.

For some time now it has been known that the physical, chemical, structural and climatological variables of the environment can interfere greatly in several clinical processes and health care, for example in the propagation of microorganisms that increase the rates of hospital infections, which affects directly the recovery of the patient ${ }^{(3)}$.

In this respect, Florence Nigthgale postulated the Environmentalist Theory, in which the direct relation that the environment, from the physical and structural dimension due to the historical context of the warfields, is explicit has with the process of healing and recovery of sick individuals. Among the variables, ventilation, illumination, temperature, cleaning, noise and odors were highlighted, demonstrating that from the control of these factors, the chance of survival of the patients was greater, which is therefore intrinsic to the premises of the currently discussed ${ }^{(4)}$.

If at that time the initial records of adverse events were imminently related to infections, nowadays, with the advent of the concepts of quality in the health and safety services of the patient, other events received more attention, according to the own emphasis of the Brazilian Health Regulatory Agency (ANVISA), for example: medication errors, safe surgery, patient identification, and prevention of skin and fall injuries ${ }^{(5)}$.

Regarding medication errors, comparisons between studies of different realities allow us to make epidemiological inferences pointing out that these are the most common types of errors in health services, as is the case in American statistics which have shown that about $1 \%$ of these errors is fatal, $12 \%$ cause irreparable sequelae to the patient, and $30 \%$ to $57 \%$ causes some short, medium or long term harm depending on the classification of the error in mild, severe or very serious, from the stage in which it occurred and from the medicine class to which medicine belongs ${ }^{(6)}$.

As regards the class of medicinal products, antimicrobials (antibacterial, antifungals, antiparasitics) which are substances that cause death or inhibition of the growth of microorganisms and can be produced by bacteria, fungi, or partially or totally synthesized, are among the most commonly prescribed medicines and also among the most commonly used medicines ${ }^{(7)}$.

Also, in Brazil, other multicenter studies have identified a high prevalence of antimicrobial errors, showing that there is a variation of $8.4 \%$ to $18.5 \%$ of errors associated with this group of medicines, especially the time errors $(87.7 \%)$ and dose $(6.9 \%)$ were the most frequent ${ }^{(8-9)}$.

Knowing that medicines are chemical substances that can change their active principle due to the way they are prepared and administered, as well as due to the oscillations of environmental variables, it is questioned: Which categories of errors are associated with the preparation and administration process of antibacterial are more present in the Medical Clinic sector of a Teaching Hospital? Is this frequency associated with environmental conditions?

The relevance of a research that seeks answers to the above questions is well understood, and it is understood that studying the errors associated with the use of antibacterial in the hospital context is important to try to avoid failures in some stages of the chain of possibility that these events may culminate an increase in the cost of more effective medicines and an extension of their time of use, as well as to draw up effective and resolutive strategies for the prevention of these incidents by means of safe practices that guarantee their rational use with a view promotion of patient health and safety.

\section{OBJECTIVE}

To identify the relationship between environmental factors and errors in the preparation and administration of antibacterial medicines.

\section{METHOD}

\section{Ethical aspects}

Throughout the execution of the project, the ethical-legal aspect was obeyed, data collection only occurred after the issuance of a favorable opinion, issued by the Human Research Ethics Committee of the Universidade Federal do Ceará, and all participants signed the Free and Clear Consent Term.

\section{Design, place of study and period}

It is an observational and cross-sectional study carried out between August and December 2014 in the Clinical Medical sectors in a teaching hospital belonging to the Sentinel Network of ANVISA, located in Fortaleza-Ceará. The sectors are divided into two nursing posts, and in general, they are responsible for occupying 114 beds distributed in the following 
specialties: dermatology, cardiology, medical clinic, endocrinology, gastroenterology, pneumology, neurology, nephrology, hematology and rheumatology.

\section{Sample and inclusion and exclusion criteria}

In order to define the total doses to be observed, that is, the sample, we requested the hospital pharmacy service of the Institution, the information about the number of doses of antibacterial, divided by shifts, dispensed for Clinics A and B in a period of thirty days prior to the start of data collection. Only antibacterial agents were included, due to the close relationship between changes in environmental conditions and the alteration of their chemical stability ${ }^{(10)}$.

The sample group of the research consisted of $40 \%$ of the doses informed by the pharmacy service. This percentage was calculated based on the average errors of preparation and administration of antimicrobial medication present in another Brazilian study $y^{(11)}$.

There were 157 observations in the Medical Clinic B: 67 in the morning, 30 in the afternoon and 60 in the evening. In Medical Clinic A, 108 doses were observed: 44 in the morning, 22 in the evening period and 42 in the evening shift.

\section{Study protocol}

The data collection was operated in days and shifts drawn by the researchers, so as to contemplate the morning, afternoon and night periods.

To achieve the proposed goal, the observations were made starting at the time of preparation and completed with complete administration of the medicine. During this period, the observer used two check-list instruments according to each of the following steps: illumination, noise, temperature, lightness and dimensioning of the physical space.

The following equipment was used: measuring tape measured in centimeters to measure the size of the physical space; Digital Incoterm TDEC100C digital meter to measure the noise level; and a Multi-Function Environment Meter 4IN1 to quantify illumination, temperature and humidity parameters. It should be noted that all equipment was certified by the National Institute of Metrology, Quality and Technology (INMETRO).

Observers were previously trained in data collection and equipment use, and to avoid the Hawthorne effect, which is common in observational studies, the 20 observations made in August were not considered for evaluation.

\section{Results analysis and statistics}

The data obtained were grouped in the SPSS database (Statistical Software for Social Science) 19.0 for statistical judgment and the Kolmogorov-Smirnov and Mann-Whitney tests were performed to identify the associations between the environmental variables and the errors of medication, as well as to establish comparisons between clinics.

\section{RESULTS}

In this study, the stages of antibacterial preparation and administration were considered in order to elucidate the research question. The results were presented in tables, sectioned in two topics: environment-related variables in the medicine preparation and administration stages; and association between environmental aspects and errors in the medicine preparation and administration stages.

The main categories of errors were: dose error (157); time error (30); and, wrong choice of medication (28).

\section{Environment-Related Variables in Medicine Preparation and Administration Stages}

The physical space destined to the stage of preparation of the medicines, in Clinic A and Clinic B, is used for other purposes, aspect that deserves to be analyzed, since the existence of an environment for the accomplishment of multitasking can present several factors that will interfere during the execution of more focal actions. The variables related to the environment analyzed in this study were: illumination, noise, temperature, humidity and physical space, as the inadequate management in the preparation and administration of these medicines can decrease the microbiological safety and therapeutic efficacy of the same.

Considering the physical conditions of the environment, as can be seen in Table 1, it is worth noting that averages outside the standard of recommendation were found according to Brazilian legislation in Clinics $A$ and $B$, respectively, in the following items: illumination (102.6 lux, 105, 6lux), noise $(59.2 \mathrm{db}, 60.5 \mathrm{db})$ and temperature $\left(29.8^{\circ} \mathrm{C}, 28.8^{\circ} \mathrm{C}\right)$. Regarding the humidity variable, an adequate mean $(61.3 \%, 62.2 \%)$ was detected for the hospital environment of medicine preparation and administration in the two sectors of the study.

Regarding the illumination of the medicine preparation places, in Clinic A, artificial light is observed, but preserves in the environment the incidence of sunlight, since the tilting windows are open; and in Clinic B, the light only comes on artificially, since the windows were closed.

As for noise, a maximum level between $70.4 \mathrm{db}$ and $78 \mathrm{db}$ variable was observed that could divert the attention of the professional when the attention is highly needed. Noise was usually caused by conversations among health professionals, use of stereos in the room, use of cell phones, and interruptions of companions during the administration process.

In the observed shifts, they presented variations between the measurements of temperature and humidity. Regarding the temperature, minimum and maximum values were obtained, respectively of $20^{\circ} \mathrm{C}$ and $37.6^{\circ} \mathrm{C}$, with average of $25.8^{\circ} \mathrm{C}$ to $29.6^{\circ} \mathrm{C}$. The high temperature is a variable present in all the shifts and that causes great physical wear to the professionals. As regards humidity, the minimum and maximum values, respectively, were $45 \%$ and $73.6 \%$, with a mean of $56.9 \%$ and $62.8 \%$ (Table 1 ).

Regarding the spaces for the administration of medicines, it was observed that in relation to ventilation and natural light there are enough windows, but some wards in the afternoon receive direct sunlight, which compromises the temperature, in addition, the windows are of the tilting type, with small opening which does not allow a satisfactory aeration. The number of beds that each ward has varies from 4 to 6 , with a routine occupation of $100 \%$, and the space between the beds is less than $2 \mathrm{~m} 2$, which compromises ventilation and the organization of the environment. 
Table 1 - Description of environmental variables during the preparation and administration of antibacterial according to clinic, Fortaleza, Ceará state, Brazil, 2014

\begin{tabular}{|c|c|c|c|c|c|c|c|c|c|c|}
\hline \multirow{3}{*}{\multicolumn{2}{|c|}{ Variable* }} & & \multicolumn{3}{|c|}{ Medical Clinic A } & \multicolumn{5}{|c|}{ Medical Clinic B } \\
\hline & & & \multicolumn{3}{|c|}{ Shift } & \multicolumn{5}{|c|}{ Shift } \\
\hline & & & Morning & Afternoon & Evening & Total & Morning & Afternoon & Evening & Total \\
\hline \multirow{12}{*}{$\begin{array}{l}\frac{\sigma}{0} \\
\frac{\pi}{\pi} \\
\frac{\pi}{0} \\
\frac{0}{2} \\
\frac{0}{2}\end{array}$} & Illumination & Medium & 102.6 & 77.9 & 22.1 & 66.3 & 95.3 & 86.4 & 24.3 & 66.5 \\
\hline & & Minimum & 79.6 & 59.6 & 20.3 & 20.3 & 81.0 & 60.0 & 20.0 & 20.0 \\
\hline & & Maximum & 140.4 & 98.3 & 25.3 & 140.4 & 102.0 & 94.0 & 28.0 & 102.0 \\
\hline & Noise & Medium & 59.2 & 59.0 & 24.0 & 45.5 & 61.2 & 69.4 & 47.7 & 57.6 \\
\hline & & Minimum & 48.9 & 50.4 & 18.2 & 18.2 & 48.0 & 54.0 & 42.0 & 42.0 \\
\hline & & Maximum & 66.8 & 70.4 & 52.3 & 70.4 & 78.0 & 78.0 & 58.0 & 78.0 \\
\hline & Temperature & Medium & 29.8 & 32.9 & 27.6 & 29.6 & 25.2 & 26.7 & 26.0 & 25.8 \\
\hline & & Minimum & 27.8 & 30.1 & 26.5 & 26.5 & 20.0 & 21.0 & 22.0 & 20.0 \\
\hline & & Maximum & 33.2 & 37.6 & 29.8 & 37.6 & 28.0 & 29.0 & 29.0 & 29.0 \\
\hline & Humidity & Medium & 61.3 & 60.5 & 65.6 & 62.8 & 57.5 & 51.2 & 59.1 & 56.9 \\
\hline & & Minimum & 57.9 & 55.3 & 59.9 & 55.3 & 45.0 & 47.0 & 50.0 & 45.0 \\
\hline & & Maximum & 66.3 & 71.9 & 73.6 & 73.6 & 68.0 & 58.0 & 63.0 & 68.0 \\
\hline \multirow{12}{*}{ 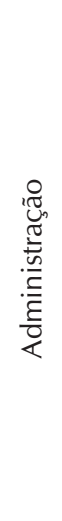 } & Illumination & Medium & 105.6 & 43.6 & 23.8 & 61.2 & 103.8 & 92.2 & 25.1 & 71.5 \\
\hline & & Minimum & 89.3 & 34.8 & 19.3 & 19.3 & 77.0 & 46.0 & 19.0 & 19.0 \\
\hline & & Maximum & 121.7 & 50.2 & 29.4 & 121.7 & 130.0 & 132.0 & 31.0 & 132.0 \\
\hline & Noise & Medium & 60.5 & 60.9 & 44.8 & 54.5 & 58.6 & 61.5 & 47.2 & 54.8 \\
\hline & & Minimum & 55.7 & 57.9 & 41.3 & 41.3 & 50.0 & 55.0 & 41.0 & 50.0 \\
\hline & & Maximum & 68.2 & 64.2 & 48.5 & 68.2 & 73.0 & 69.0 & 55.0 & 73.0 \\
\hline & Temperature & Medium & 28.8 & 28.0 & 27.1 & 28.0 & 27.6 & 28.4 & 27.3 & 27.6 \\
\hline & & Minimum & 26.4 & 27.0 & 25.2 & 25.2 & 26.0 & 25.0 & 26.0 & 25.0 \\
\hline & & Maximum & 30.8 & 29.0 & 28.4 & 30.8 & 30.0 & 31.0 & 29.0 & 31.0 \\
\hline & Humidity & Medium & 62.2 & 62.6 & 62.5 & 62.4 & 62.6 & 58.3 & 68.5 & 64.0 \\
\hline & & Minimum & 57.9 & 59.7 & 59.0 & 57.9 & 53.0 & 53.0 & 59.0 & 53.0 \\
\hline & & Maximum & 72.1 & 66.8 & 67.3 & 72.1 & 71.0 & 69.0 & 75.0 & 75.0 \\
\hline
\end{tabular}

Note: * Recomended parameters: illumination (150lux); noise $(35 \mathrm{db}$ a $45 \mathrm{db})$; temperature $\left(20^{\circ} \mathrm{C}\right.$ a $\left.23^{\circ} \mathrm{C}\right)$; humidity ( $\left.>40 \%\right)$.

Table 2 - Association between the variables error of dose and erroneous choice of medication versus average of the items of illumination and noise during the stages of preparation and administration of antibacterial in Clinics A and B, Fortaleza, Ceará state, Brazil, 2014

\section{Medical Clinic A}

\begin{tabular}{|c|c|c|c|c|c|}
\hline \multirow[t]{2}{*}{ Stage } & \multirow[t]{2}{*}{ Error } & \multicolumn{2}{|c|}{ Mann-Whitney } & \multicolumn{2}{|c|}{ Kolmogorov-Smirnov } \\
\hline & & Illumination & Noise & Illumination & Noise \\
\hline \multirow{2}{*}{ 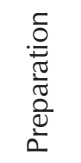 } & Dose Error & 0.106 & 0.071 & 0.241 & 0.122 \\
\hline & Wrong Medication Choice & 0.318 & 0.847 & 0.828 & 0.877 \\
\hline \multirow{2}{*}{ 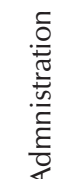 } & Dose Error & 0.781 & 0.328 & 0.988 & 0.578 \\
\hline & Wrong Medication Choice & 0.958 & 0.608 & 0.954 & 0.769 \\
\hline
\end{tabular}


Medical Clinic B

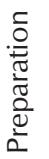

Dose Error

0.461

0.183

0.987

0.651

0.254
0.461

0.322

0.597

0.765
0.981

0.289

0.682

0.471
In the wards there are usually one or two fans, which are insufficient for their dimensions; however, they are necessary because in the city of Fortaleza temperatures are almost always above $25^{\circ}$ $\mathrm{C}$ throughout the year. It is considered that on the aspect of the use of ventilators in wards there is a probability that they favor the dispersion of suspended microorganisms in the air, which can contact with leftover antibacterial waste near the common garbage equipment in the wards themselves and increase resistance of certain strains.

As for illumination, natural daylight is used during the day, although fluorescent lamps are sometimes used and bed lamps are also used in some beds. When evaluating the levels of luminosity were found levels far below that recommended that is 150lux, and the night shift had the lowest measured value that was 19lux. This low luminosity can interfere greatly in medicine safety, and associated with the habit of transporting all the medicines of a certain ward in the same tray, can potentiate the exchange of medicines due to the difficulty to read properly what is written in the labels.

The dimensions of the preparation environments correspond to $3.8 \mathrm{~m}^{2}$ in Clinic A and 6,1 $\mathrm{m}^{2}$ in Clinic B, and are located in a central position to the wards. The space for preparation of medicine in Clinic $A$ is smaller, because the minimum size required by the legislation that is $6 \mathrm{~m}^{2}$ was not reached, which caused many restrictions of movement of professionals within the sector, and the environment is arranged: individual doses of medicines to be used during the 24 hours, sink, serum material, etc. In Clinic B, the space is also intended for the preparation of medicine and also a place where the technicians are talking in the intervals between one activity and another. In this environment there are a table, benches, chairs, a refrigerator for medicines and cabinets to store other materials such as equipment, serums, syringes, probes, etc.

It was verified that the wards are very similar both in Clinic A and Clinic B. And, regarding the local variables for hand hygiene and humidity were adequate, which is very positive, but the other environmental variables such as: illumination, noise and temperature did not meet the minimum requirements for the maintenance of an environment that promotes the reduction of errors with medicines.

When discussing patient safety in relation to health care, it is important to note that safe care starts with the provision of a safe working condition, which includes adequate environmental conditions.
Data on the environmental variables presented are extremely worrying, since in general, when associated with insufficiently qualified human resources, they can become predisposing factors to medicine error.

Association between environmental aspects and errors in the stages of medicine preparation and administration

In this research 157 dose errors and 62 wrong medicine choices were identified. Dose errors were verified from the incompatibility between the prescribed dose and the prepared / administered dose as evidenced by medicine residues in the vial, solution pockets (diluent and medicament), or in equipment. Considering that the proposed observational method did not allow the intervention of the observers, when one of these errors was identified, notification was made to the Institution's Risk Management. These categories were then matched to the environmental variables of illumination and noise to test the hypothesis that changes in luminosity and situations of auditory distractions could cooperate to increase errors in the choice of medication or in the performance of the prescribed dosage.

No association tests were performed with the variables of temperature and humidity since their influence basically depends on the alteration of the physico-chemical properties of the medicine, which would require pharmacokinetic and pharmacodynamic analysis of the antibiotics, and these were not the objectives of the study.

In order to establish statistical relationships it was necessary to compare the means of illumination and noise levels in the two chosen error variables and it was observed that in Clinics A and $B$, in the preparation and administration of antibacterial, the levels of illumination and noise, when there was a dose error or not, were very close, with an average difference of 5 percentage points, which can not be considered as a factor attributable to these errors.

Thus, it is inferred that in any environment, preparation or administration, dosing error or wrong choice of the medicament had the same level of illumination and noise in the handling of the medicaments and therefore, there was no influence on the dosing error or wrong choice of the medicine.

\section{DISCUSSION}

The environmental issue has been increasingly discussed and incorporated in the discussions that involve the health-disease 
process. There is evidence of the need to consider the dimension about the environment in relation to actions pertinent to health services, as well as to enable strategic actions aimed at (re) thinking about health practices and their consequent implications for patient safety ${ }^{(12)}$.

On the epidemic with errors involving medicines in hospital institutions, a study in Shiraz, southwest Iran evaluated a sample of 202 patients who were exposed to several medicine classes during the treatment of the underlying disease, and it was identified that not only antimicrobials are the most commonly used medicines, as are those where errors occur most frequently, at a percentage of $24.3 \%{ }^{(13)}$.

There is still some limitation on the evidence that shows a significant relationship between environmental variables and declining quality of care and patient safety, and recommend that studies be conducted in different realities of care (primary, secondary, tertiary) with a view to a more robust diagnosis and planning of physical environments that reduce the incidence of avoidable adverse events, such as those related to medications ${ }^{(3)}$.

In order to guarantee the safety related to its use, it is indispensable that, in addition to the correct clinical indication by the physician and handling during the preparation and administration by the nursing professional, environmental conditions are maintained that conserve the active principle (illumination, humidity) and provide greater concentration and functionality (noise level, cleaning and dimensioning of the physical space).

The physical structure of the various environments that make up the hospital should focus on meeting three prerequisites: functional, technical and psychosocial. Thus, in the context of functionality, providing and maintaining the organized environment is a factor that certainly facilitates work processes, speeds up the performance of tasks and, mainly, cooperates with the provision of safer care ${ }^{(14)}$.

Studies that evaluate the impact of environmental factors on the development of care are still strongly focused on the surgical block ${ }^{(15-16)}$, although some research has sought to highlight them as being important for the practice of medicine preparation, preparation and administration ${ }^{(7,17)}$.

RDC 307, which changed DRC 50, is the legal document that regulates the minimum guidelines to be adopted by health establishments in Brazil regarding the physical and architectural aspects of their built area. It describes that, regardless of the care complexity, minimum conditions of comfort and ergonomics should be offered to professionals and patients, as well as through planning in cooperation with engineers, architects and health workers, creating barriers to reduce hospital infections ${ }^{(18)}$.

Specifically in the case of medicine preparation and administration, because it is a task that requires excessive attention and visual precision, the appropriate place should meet the following requirements: $6 \mathrm{~m}^{2}$ physical dimensioning, since the preparation is performed at the nursing station, and $1 \mathrm{~m}$ between the beds in the case of administration, since this is performed in the ward; noise level from $35 \mathrm{db}$ to $45 \mathrm{db}$; incidence of luminosity of 150 lux; humidity not less than $40 \%$; and temperature between $20^{\circ} \mathrm{C}$ and $23^{\circ} \mathrm{C}^{(19-21)}$.

Although there have been significant fluctuations in illumination and noise values, these factors could not be attributed to errors in dose or wrong choice of medication. However, these variations should be considered and biochemical analyzes of the medicines should be carried out in subsequent studies to verify the impact they cause in the alteration or even inactivation of the active principle of the antibiotics.

It is interesting to mention the research developed in the Intensive Care Unit that registered in the morning the highest levels of noise, related to the greater flow of people, a greater number of activities performed, such as the exchange of equipment that facilitates the triggering of alarms, collection of exams and bed organization. The authors emphasize that professionals need to remember this condition and listen to their voice when they answer phones and talk to other people who share the same work space ${ }^{(22)}$.

It is known that the illumination above the reference values recommended by the manufacturers of the antibiotics may precipitate oxidation or hydrolysis reactions, which contributes to the degradation of the medicine molecules and changes the pharmacokinetic and pharmacodynamic characteristics ${ }^{(10)}$.

Most of the antibiotics that composed the sample of this research have in the recommendations of storage, conservation and administration the care to protect from light, such as, for example, Metronidazole, which due to its photosensitivity characteristics can not be exposed to ambient light due to the risk of photodegeneration ${ }^{(23)}$.

Consideration should be given to the need for appropriate environments for the preparation and administration of medications, but also to take into account that there should be an incidence of luminosity that is sufficient to guarantee good condition and visual comfort to the nursing professional.

Noise level is an extremely important factor in increasing the occurrence of medication errors. Values far above what was recommended by national legislation were found, since in some circumstances these figures reached $78 \mathrm{db}$. Thus, it is recommended that noise levels be measured frequently in health institutions, especially in sectors where there is a higher concentration requirement for performing tasks, such as in the medicine preparation room ${ }^{(24)}$.

The noise generated in the hospital environment can affect the communication among professionals, thus reducing the understanding of information and consequently the correct execution of certain actions issued by verbal command that are still very frequent in most institutions in Brazil.

On the temperature, a peak of $37.6^{\circ} \mathrm{C}$ with average between $28^{\circ} \mathrm{C}$ and $29.6^{\circ} \mathrm{C}$ was found in the different shifts in the two clinics during the preparation phase. Medicinal products such as Ceftriaxone, Teicoplanin and Ciprofloxacin should not be exposed to temperatures below $15^{\circ} \mathrm{C}$ and greater than $30^{\circ} \mathrm{C}$ prior to reconstitution, as indicated by manufacturers (25-26). In the case of Oxacillin, for example, this range further reduces, since the solution after reconstitution remains active for three days only if the temperature is between $15^{\circ} \mathrm{C}$ and $25^{\circ} \mathrm{C}^{(27)}$.

In general, the increase in ambient temperature influences the rate of degradation of the solutions, causing $\mathrm{pH}$ changes and consequent pharmacological instability. Thus, based on the excessive temperature observed, especially during the afternoon in the studied units, it may be possible that some patients may be exposed to antibiotics with diminished efficacy. 
Moisture refers to the percentage of water vapor mixed with circulating air in the environment, and was investigated in this study because there is evidence that its decrease below suggested levels can cause important risks in the hospital environment, for example: increase the dispersion of gases inflammations and aerosols; predispose to greater survival of viruses, bacteria and fungi, as well as to accelerate the growth of the latter; and finally, to make patients more susceptible to respiratory infections due to dryness of the nasal cavity ${ }^{(16)}$.

All the antibiotics that composed the sample group of this research are indicated to be kept in places protected from extremes of humidity so that they do not find favorable conditions to increase the microbiological reproducibility and favor the emergence of more resistant bacterial strains. For this topic, no values below $40 \%$ were found, which can be attributed to the warm and tropical climate prevailing in the city of Fortaleza, which presents a mean humidity above $55 \%$ during all months of the year ${ }^{(28)}$.

In this way, the inferences presented by this research agree with those of another study ${ }^{(24)}$, because they indicate that when there is greater variation of environmental conditions, proportionately also the frequency with which the errors of medication will occur, or if they do not happen, the system has fewer barriers limiting this type of event.

Human errors occur in the contexts of nursing care, and studies in this area lead to reflect on the importance of developing further research at both international and national level because nurses are at the forefront and their practice deliberately includes prevention of errors and promoting patient safety. Thus, it is very relevant to report the errors of clinical practices at institutional level, not in the sense of blame, but with the aim of creating a positive culture against error, in order to modify behaviors that allow the development of quality of care and thus contribute to patient safety ${ }^{(2)}$.

Thus, it is urgent that strategies to prevent errors with medicines in hospitals be put in place, and emphasize that the creation of indicators that also include the verification of environmental conditions, as well as the functional architectural planning that guarantees microbiological safety of the sectors, are measures to ensure the safety of professionals and patients ${ }^{(29)}$.

Often, in practice, the issues raised in this study are results of deficiencies in the nursing staff's system and work process, such as the lack of a pharmacist in clinics daily, although nurses, administrators and other health professionals seek to minimize factors causing errors by making use of "goodwill", but administrative aspects and human and material resources are also necessary to reduce the chain of these factors. It is important to use the findings of this study to seek to solve problems and explore potential improvements by making use of available resources.

After the research, it is suggested that the emergency measures, both behavioral and environmental, be implemented to ensure greater medicine safety, such as: continuous training in service with nursing professionals on assertive practices regarding the handling of antibiotics; the performance of simulated practices; the more active participation of hospital engineering in hospital infection control services; periodic training on the rational use of antibacterial; the use of automated technologies to detect sudden oscillations in environmental conditions and the immediate correction of nonconformities; a better distribution of tasks among nursing professionals; the prohibition of agents causing unnecessary noise in the preparation environment of medicines, such as the use of headphones, microsystem devices and heavy traffic of other professionals in the area; and dissemination with easy and quick access to the guidelines that guide the optimal conditions of antibacterial preparation and administration.

\section{Study limitations}

Some limitations can be pointed out regarding the accomplishment of this research, such as: the impossibility of calculating the safety rate and prevalence of errors, since the sample was composed only by doses in which there was an error; the inclusion of the air velocity parameter in the sectors, which could identify the micro-organism favorable dispersion conditions; no biochemical analyzes were performed on antibacterial after exposure to environmental factors incompatible with the maintenance of their stability; the actual volumetric losses of antibiotics were not measured where there was an underdose error.

\section{Contributions to the nursing field}

It is intended that this research may alert health managers and professionals about medication errors, drawing special attention to the preparation and administration phases and their interfaces with minimum environmental requirements to ensure more safety in the use of antibiotics, so that in the long term may lead to changes in the conditions favoring adverse events, and may also be a tool for building a local safety plan to reduce bacterial resistance, hospital infection rates and increase patient safety.

\section{CONCLUSION}

The main categories of errors were: dose error (157); time error (30); and wrong choice of medication (28).

Regarding the influence of environmental factors, it was verified that the physical space for the preparation was inadequate in Medical Clinic A $(3.8 \mathrm{~m} 2)$, and the items illumination, temperature and noise were extremely oscillating in the three shifts and in the two clinics, with averages generally above recommended for the interior of the hospital environments. However, illumination and noise variations were not statistically significant to cause dose errors or medicine misuse $(p>0.05)$.

Aspects of physical structure must be considered, which makes it necessary to know the specific legislation in force during space planning, in order to promote a safe environment. However, what is much observed is an adaptation of spaces, often disregarding aspects of dimension, illumination, noise, and even ideal working conditions for the nursing team.

It is recommended for further study that the accuracy of the task and the background reflectance (ratio of the amount of light emitted to that of light reflected on a surface) should be added in the analysis of the illumination aspect, which will robustness to the direct relationship that can be established between this variable and the occurrence of errors with medications, as well as biochemical and microbiological analyzes of the medicines after preparation, which were the limitations of the study. 


\section{REFERENCES}

1. Rigobello MCG, Carvalho REFL, Cassiani SHB, Galon T, Capucho HC, Deus NN. The climate of patient safety: perception of nursing professionals. Acta Paul Enferm [Internet]. 2012 [cited 2015 Nov 02];25(5):728-35. Available from: http://dx.doi. org/10.1590/S0103-21002012000500013

2. Oliveira RM, Leitão IMTA, Aguiar LL, Oliveira ACS, Gazos DM, Silva LMS, et al. Evaluating the intervening factors in patient safety: focusing on hospital nursing staff. Rev Esc Enferm USP [Internet]. 2015 [cited 2015 Nov 02];49(1):104-13. Available from: http://dx.doi.org/10.1590/S0080-623420150000100014

3. Gurses AP, Pronovost PJ. Physical environment design for improving patient safety. HERD [Internet]. 2011 [cited 2015 Oct 10];5(1):1-5. Available from: https://www.ncbi.nlm.nih.gov/pubmed/22322632

4. Frello AT, Carraro TE. Florence Nightingale's contributions: an integrative review of the literature. Esc Anna Nery Rev Enferm [Internet]. 2013 [cited 2015 Nov 05];17(3):573-9. Available from: http://dx.doi.org/10.1590/S1414-81452013000300024.

5. Brasil. Ministério da Saúde. Portaria No 529/2013: institui o Programa Nacional de Segurança do Paciente (PNSP). Brasília: Ministério da Saúde; 2013.

6. Tromp M, Natsch S, Achterberg TV. The preparation and administration of intravenous drugs before and after protocol implementation. Pharm World Sci [Internet]. 2009 [cited 2015 Nov 05];31:413-20. Available from: http://www.ncbi.nlm.nih. gov/pubmed/19051054

7. Jennane N, Madani N, OuldErrkhis R, Abidi K, Khoudri I, Belayachi J, et al. Incidence of medication errors in a Moroccan medical intensive care unit. Int Arch Med [Internet]. 2011 [cited 2015 Oct 23];4(32):1-7. Available from: doi:10.1186/1755-7682-4-32

8. Marques TC, Reis AMM, Silva AEBC, Gimenes FRE, Opitz SP, Teixeira TCA, et al. Erros de administração de antimicrobianos identificados em um estudo multicêntrico brasileiro. Rev Bras Cienc Farm [Internet]. 2008[cited 2015 Nov 10];44(22):305-14. Available from: http://dx.doi.org/10.1590/S1516-93322008000200016

9. Gimenes FRE, Mota MLM, Teixeira TCA, Silva AEBC, Opitz SP, Cassiani SHB. Patient safety in drug therapy and the influence of the prescription in dose errors. Rev Latino-Am Enfermagem [Internet]. 2010 [cited 2015 Nov 10];18(6):1055-61. Available from: http://dx.doi.org/10.1590/S0104-11692010000600003

10. Crepaldi RMC, Monteiro C, Peterlini MAS, Pedreira MLG. Hydrogen-lon potential of antibiotics according to the environment factors temperature and luminosity. Rev Latino-Am Enfermagem [Internet]. 2010 [cited 2015 Oct 8]; 18(2):09 telas. Available from: http://dx.doi.org/10.1590/S0104-11692010000200020

11. Silva AEBC, Cassiani SHB. Prospective risk of the anti-infective medication administration process. Rev Latino-Am Enfermagem [Internet]. 2013 [cited 2015 Oct 8];21(esp):9 telas. Available from: http://dx.doi.org/10.1590/S0104-11692013000700029

12. Liu W, Manias E, Gerdtz M. The effects of physical environments in medical wards on medication communication processes affecting patient safety. Health Place [Internet]. 2014 [cited 2015 Oct 13];26:188-98. Available from: http://dx.doi.org/10.1016/j. healthplace.2013.12.017

13. Vazin A, Zamini Z, Hatam N. Frequency of medication erros in an emergency department of a large teaching hospital in Southern Iran. Drug Healthc Patient Saf. [Internet]. 2014 [cited 2015 Dec 3];6:179-84. Available from: http://dx.doi.org/10.2147/DHPS.S75223

14. Duarte SCM, Stipp MAC, Silva MM, Oliveira FT. Adverse events and safety in nursing care. Rev Bras Enferm [Internet]. 2015 [cited 2016 Jan 4];68(1):144-54. Available from: http://dx.doi.org/10.1590/0034-7167.2015680120p

15. Barreto RASS, Rocha-Vilefort LO, Souza ACS, Prado-Palos MA, Barbosa MA, Borges VPFN. Processo de limpeza da sala operatória: riscos à saúde do usuário e trabalhador. Rev Eletr Enf [Internet]. 2011 [cited 2015 Dec 13];13(2):269-75. Available from: http:// dx.doi.org/10.5216/ree.v13i2.9191

16. Sevilha HA, Paiva LSJ, Poveda VB. Análise das variáveis ambientais em salas cirúrgicas: fontes de contaminação. Rev SOBECC [Internet]. 2014 [cited 2015 Dec 13];19(3):123-8. Available from: http://doi.editoracubo.com.br/10.4322/sobecc.2014.019

17. Silva MDG, Rosa MB, Franklin BD, Reis AMM, Anchieta LMA, Mota JAC. Concomitant prescribing and dispensing errors at a Brazilian hospital: a descriptive study. Clinics [Internet]. 2011 [cited 2015 Dec 10];66(10):1691-97. Available from: http://dx.doi. org/10.1590/S1807-59322011001000005

18. Brasil. Agência Nacional de Vigilância Sanitária. RDC $n^{\circ}$ 307, de 14 de novembro de 2002. Altera a Resolução RDC nº 50 de 21 de fevereiro de 2002 que dispõe sobre o Regulamento Técnico para planejamento, programação, elaboração e avaliação de projetos físicos de estabelecimentos assistenciais de saúde. Brasília: Ministério da Saúde; 2002.

19. Brasil. Associação Brasileira de Normas Técnicas. NBR 10152: Níveis de ruído para conforto acústico. Rio de Janeiro: ABNT; 1987.

20. Brasil. Associação Brasileira de Normas Técnicas. NBR 5413: Iluminância de interiores. Rio de Janeiro: ABNT; 1992.

21. Brasil. Ministério do Trabalho e Previdência Social. NR 17 - ergonomia. Brasília: Ministério do Trabalho e Previdência Social; 2007.

22. Cardoso MVLML, Chaves EMD, Bezerra MGA. [Noise and sounds in the neonatal unit]. Rev Bras Enferm [Internet]. 2010 [cited 2016 Jan 6];63(4):561-66. Available from: http://dx.doi.org/10.1590/S0034-71672010000400010 Portuguese 
23. Metronizadol injetável: recomendações aos profissionais. Suzano: Sanofi-Aventis; 2008.

24. Mahmood A, Chaudhury H, Gaumont A. Environmental issues related to medication errors in long-term care: lessons from the literature. HERD [Internet]. 2009 [cited 2015 Dec 13];2(2):42-59. Available from: http://www.ncbi.nlm.nih.gov/pubmed/21161929

25. Bula profissional Ciprofloxacino genérico injetável. Goiás: Haex-Istar; 2015.

26. Antibióticos do Brasil. Teicoplanina. Brasília: ABL; 2015.

27. Oxacilina sódica: modelo de bula com informações técnicas aos profissionais de saúde. Goiás: Teuto; 2015.

28. Fundação Cearense de Meteorologia e Recursos Hídricos. Variáveis meteorológicas. Fortaleza: Secretaria de Recursos Hídricos; 2015.

29. Cheng R, Yoo L, Ho C, Kadija M. Identification of medication safety indicators in acute care settings for public reporting in Ontario. Healthc Q [Internet]. 2010 [cited 2015 Nov 13];13(spec):26-34. Available from: http://www.ncbi.nlm.nih.gov/pubmed/20959727 